\section{POLITICS AND THE WORLD ARCHAEOLOGICAL CONGRESS [-3]}

\author{
LA POLÍTICA Y EL CONGRESO \\ ARQUEOLÓGICO MUNDIAL [-3]
}

\section{NANDINI RAO (*)}

\section{SUMMARY}

The recognition in the West that every discipline is influenced by its socio-political context led to the demand for reflexive archaeology and to the formation in 1986, by the 'politically aware', of the World Archaeological Congress (WAC). WAC explicitly recognises the socio-political context of archaeological practice, and archaelogy's political, social and academic responsibilities. The Congress, which meets every four years, met in India in December 1994.

Indian archaeologists have largely denied the influence of socio-political contexts on academics. But this has not prevented some from (mis)using archaeological evidence to further political ends with catastrophic results. No discussion on the issue was permitted at the Congress so that eight years after it was formed. the WAC compromised and suppressed free debate on a vital matter.

This essay outlines the genesis of WAC and the reasons why it was formed, before analysing the Indian context of the third meeting of the Congress. It also examines the response of Indian archaeologists at WAC to the protest against such political abuse of archaeology and calls for a reflection on whether WAC has achieved its objective of becoming a relevant world organisation.

\section{RESUMEN}

El reconocimiento en Occidente de que cada disciplina está influida por su contexto socio-político llevó a la

(*) 3-5-820 Hyderguda. Hyderabad, 500001 . India. El artículo fue remitido en su versión final el 7-IV-95. reivindicación de una arqueologia reflexiva y a la formación én 1986, por los arqueólogos "políticamente conscientes", del Congreso Arqueológico Mundial (WAC). El WAC reconoce explicitamente el contexto sociopolítico de la práctica arqueológica y las responsabilidades políticas, sociales y académicas de la arqueología. El Congreso, que se celebra cada cuatro años, tuvo lugar en India en diciembre de 1994.

Los arqueólogos indios han negado durante mucho tiempo la influencia de los contextos socio-politicos sobre los investigadores. Pero ello no ha impedido que algunos de ellos hayan utilizado de forma incorrecta la evidencia arqueológica con objetivos políticos ulteriores y resultados catastróficos. En el Congreso no se permitió ninguna discusión sobre este tema de forma que, ocho años después de su creación, el WAC transigió y suprimió un debate abierto sobre un asunto vital.

Este artículo esboza la génesis del WAC y las razones por las cuales se constituyó, antes de analizar el contexto indio de la tercera reunión del Congreso. También examina la respuesta de los arqueólogos indios en el WAC en relación con la protesta contra tal abuso político de la arqueología y reclama una reflexión sobre si el WAC ha logrado su objetivo de llegar a ser una organización mundial significativa.

Key words: Archaeology and Politics. Ayodhya. Babri Masjid. Hindu resurgence. Hindu Right. Indian identityformation. Ramayana sites. Ramjanmabhoomi. Sacred places. Socio-political context of archaeology. WAC. WAC-3

Palabras clave: Arqueología y Política. Ayodhya. Babri Masjid. Resurgimiento hindú. Derecho hindú. Forma- 
cion de la identidad hindu. Yacimiento Ramayana. Ramjanmabhoomi. Lugares sagrados. Contexto sociopolitico de la arquesologia. Congreso Arqueológico Mundial. Congreso Arquesoligicos Mundial -3.

\section{THE GENESIS OF THE WORLD ARCHAEOLOGICAL CONGRESS (WAC)}

It is often assumed that archaeology is, or should aspire to be, the value-free investigation and reconstruction of past societies. This has meant that an awareness of its political nature did not emerge until recently. Through the 1970 s and $80 \mathrm{~s}$, the contributions of Roland Barthes, Michel Foucault, Edward Said and others influenced archaeology in Europe especially, but also the United States. With this came the demand for reflexive academics. With it also came the recognition/admission that the past is reconstructed as a strategic reflection of the present and the question of whether it ought to remain an unthinking acceptance of the statusquo or become a critical/emancipatory practice. A significant number still argue, however, that archaeology (and all academics) is value-free. Others agree that this is neither possible, nor perhaps desirable and concepts such as 'power', 'ideology' and 'praxis', "derived from Marxist, Critical Theoretical and other Social Scientific thinking, embodie[d] a change ... both substantive and effecting the constitutive premises for the practice of archaeology" (Pratap and Rao, 1986: 4). Miller's "Archaeology and Development" (1980) and Langford's "Our Heritage ... Your Playground" (1983) revealed the inherently political nature of archaeological practice and this was underscored by WAC-1 and the developments preceding it.

In Academic Freedom and Apartheid, Peter Ucko (1987) explains how and why the WAC came into being. From the moribund (at least from the perspective of the non-European world) and Eurocentric UISPP set up in 1931 to WAC in 1986, archaeology had come a long way. Until 1986, the UISPP was "the only institution with an international responsibility for archaeology" (Champion and Shennan, 1986: 109) but part of the problem lay in the fact that in the case of the UISPP at least, "international" really meant issues that interested Europeans. This was evident in the facts that the meetings held every four years were only once ever held outside Europe and the sessions at the meetings were "organised around European perceptions of archaeology" and what European archaeologists considered to be of interest (Champion and Shennan, 1986: 110). There was also a shocking lack of understanding of archaeological issues in the rest of the world (including the Americas) and sessions on the Iron Age of America con-tinued to be held although no such age had been known to exist! Further, there was uncertainty in non-European countries as to the structure of the UISPP and few non-European archaeologists attended either the congresses or the smaller meetings organised between. The UISPP had clearly "failed to ad-just to the changing nature of the world and of archaeology in particular" (Champion and Shennan, 1986: 109).

Ucko, who had been given the task of organising the 1986 UISPP Congress (later the WAC) wanted to ensure that as many countries as possible were represented at the Congress. $\mathrm{He}$ was concerned that few knew how the UISPP functioned and how it was organised, and that it was undemocratic (1). Furthermore, to Ucko, Third and Fourth World participation at the Congress was crucial. He also wanted it to be a serious academic congress and to create an organisation through which "a secure future for world archaeology" could be established, and "make its contribution to the recognition of the unique variety of human cultures, past and present" (Ucko, 1987: 5). Students were encouraged to participate as were those involved in reconstructing/working with the past, but who had previously not necessarily been recognised as archaeologists (Ucko, 1987: 25-26). It was evident that the 1986 Congress would be a pathbreaker.

As a Third World student in Britain in the years immediately before and after WAC-1. I

(1) Unfortunately, the WAC has not really been able to overcome this problem, and the structure of its organisation remains a mystery to many. Most of us do not know whether we are members of WAC or merely members of a Congress. We receive no information, newsletters or bulletins. Even while stating that the WAC was organised in the most democratic of ways, Ucko (1987: 20) mentions that one of his jobs was to ensure that "the right participants from each country could really get the grants they needed to be able to attend" WAC-1. One wonders how he was in a position to decide "right" from "wrong" participant. 
watched the unfolding of the events around the Congress with anticipation. Fellow Third Worlders and I had always felt that archaeology in Europe and the United States ignored developments in the rest of the world. Volumes analysing and tracing theoretical developments and disciplinary change ignored those occurring in the South (2). A disciplinary 'lag' became evident too, as turgid texts on theoretical archaeology became the norm in Western Europe and the U.S., while in India, the data-heavy descriptions of carefully and 'scientifically' excavated material continued to be regarded as crucial, even the 'real stuff'. Post-processual, feminist and critical archaeology were viewed with suspicion as distant theoretical rumblings which had little to do with what constituted 'real' archaelogy. The 'lag' became more pronounced as scholars in the West increasingly accepted that the socio-political context of archaeological practice influenced the discipline (3). Indian archaeologists, by and large, do not accept this and continue to view archaeology as being above and incorruptible by socio-politics.

In an attempt to bring the archaeology of the South into sharper focus in the West, a colleague and I were to edit as issue of the Archaeological Re iew from Cambridge on archaeology in the contemporary Third and Fourth World contexts. Meanwhile, Steve Shennan seconded the motion of the Pan African Association on Prehistory and Related Studies, banning contact with South Africa. The reverberations of this ban on South African/Namibian participation soon began to resound and we felt it was imperative in the circumstances to focus the $A R C$ issue on the interlinkages between archaeological theory, practice and contemporary sociopolitics. In spring 1986. Archaeology and Politics, the fifth volume of $A R C$ was published. The volume was one of the firts few to acknowledge the inherently political nature of archaeology and revealed the ways in which modern nation states and the bourgeoisie used history and archaeo-

(2) I have used the word 'South' and the phrase 'Third and Fourth Worlds' interchangeably. Further, I have used the term "West" to indicate the wealthier and more dominant nations of the world, including among others, the U.S.A., Australia and those in Europe.

(3) It will become clearer in the pages that follow, that several archaeologists in the West do not accept this. But, in India, there are even fewer who do and their voices are rarely heard. logy to oppress groups, maintain the status-quo and create myths to legitimise their ideologies and actions.

Shennan made the WAC (Ucko, 1987: 37-8, 53-4) reflect in action, what had until then been merely an important 'concern'; by seconding the motion, he ensured that archaeologists saw the relation between archaeology and politics, and that archaeology was in fact, practiced within a political context revealing "its social responsibility beyond its essentially academic function". Shennan's action left the organisers of WAC little choice. After working hard at making the 1986 Congress something worthwhile, this move nearly resulted in the Congress' being scrapped altogether. As is well known, the archaeological community around the world was cleaved in two, with some supporting the ban on South African participation and others vociferously objecting to what they saw as an infringement of "academic freedom" (see Shaw, 1986 for a discussion on academic freedom). Many outside Europe (and also in Britain and America) felt that the ban was an infringement of academic freedom. Ucko (1987: 54) himself initially wavered ("God knows what you have done to our Congress" he had said to Shennan at the time before taking the 'pro-ban' stand.

I will not discuss the 'pro-' or 'anti-ban' arguments here, except to say that for some of us from the Third World who saw oppression expressed (at international, national and domestic levels) in various ways, people objecting to an infringement of academic freedom seemed to be somewhat self-indulgent. We hoped, expected and anticipated that through the WAC, archaeologists would finally admit that reconstructing the past was also a political enterprise, that the past was in and of itself political and that people who dealt with (and in) the past had a social and political responsibility.

Those who felt that archaeology was in some way reduced through the recognition of its political nature were legion and they expressed their anger at the ban in surprisingly virulent ways. Despite the odds, the World Archaeological Congress did take place and was a remarkable success. As Hubert stated subsequently, "... not only had the WAC succeeded in being a world event .... it also re-directed the course of archaeology, irrevocably, into a new direction" (cited in Ucko, 1987: 164). 


\section{AYODHYA AND WAC-3}

In 1986 when WAC-1 was held, most Indian archaeologists claimed they were against apartheid, but not against South African archaeologists' and maintained that archaeology and apartheid belonged in different, mutually exclusive domains: the former in academics and the latter in politics - the one being an "objective" and "scientific" study of the past and the other, the concern of a bunch of disreputable and corrupt people (4). As in much of Europe and America, any acknowledgement or discussion of the relationship between politics and archaeology remains taboo in India and Kossinna's dabblings in his Aryan theories have, in common understanding, become "the symbol of archaeological politics" (Pratap and Rao, 1986: 3) (5).

Discussions with several Indian archaeo- logists who went to Southampton revealed that their participation in WAC-1 in no way reflected their stand on the issue of the ban. They were at Southampton because WAC-1 provided a rare opportunity: one where several hundred wellknown scholars were to discuss their work, and where funds enabling Third World participants to attend were available. Few who went were in any way concerned about the South African issue, and if they were, their concern was primarily that archaeology was being 'politicised'.

Such a view of the relationship between politics and archaeology remains in India despite the fact that recently, archaeology has become embroiled in an obvious political controversy.

(4) I will not discuss here the notion that politics and academics belong in different domains, wherein the latter is seen to be neutral and value free. Nor will I discuss how archaeologists in India have come to believe that incorporating scientific techniques into archaeology has made it into a "scientific" and "objective" discipline and therefore ensured that socio-politics does not impinge upon it (for a discussion, see Rao, 1987).

(5) Although Said (1985: 10) emphasised a decade ago that "No one has ever devised a method for detaching the scholar from the circumstances of life, from the fact of his involvement (conscious or unconscious) with a class, a set of beliefs, a social position, or from the mere activity of being a member of society" and that these "continue to bear on what he does professionally", few Indian archaeologists are willing to accept the socio-political context of contemporary archaeological practice.
The sharply political nature of archaeology was recently revealed when rival groups in India laid claim to certain areas ("sacred places"). The groups have used historical (colonial documents and police records) and archaeological 'evidence' (reports - mainly unpublished - of excavations conducted) as well as myth, oral tradition and finally also 'emotion' to legitimise these claims. The outcome has been catastrophic in terms of the violence and bloodshed that have resulted.

\section{THE CONTROVERSY}

A mosque (the Babri Masjid) erected in the northern Indian city of Ayodhya, in which Muslims offered prayers from the mid-1500s to 1949 , was destroyed by Hindu fundamentalists in December 1992. They claimed it to be situated on the ruins of a temple (razed by the first Mughal emperor, Babur) which commemorated the birth (janma) of their god/king, Rama (whose story is told in the epic poem, the Ramayana). Muslims and Hindus have both appealed to historical/archaeological facts to support their positions. Archaeologists have provided 'evidence' and opinions on the issue of whether or not a temple existed below the mosque (see Historians' Forum, n.d.; Mandal, 1993 and Srivastav, 1991).

In the post-colonial context, when Indian identity (reduced and denigrated in the encounter with colonialism and Partition) was sought to be re-created, tradition and continuity were emphasised and Indian culture was proclaimed to be unsullied by 'external' (especially Islamic and colonial) contact. A Hindu resurgence and the creation of Muslim Pakistan in some ways directed the course of Indian identity-formation towards the manipulation of symbols from a "pre-Muslim" past. Archaeologists and historians contributed in no small measure to the re-creation of the post-colonial Indian identity. Archaeology became centred largely around the excavation of pre-Mughal and '-Muslim' eras (ie, pre-eleventh century AD), with an emphasis on the Guptan age (between the fourth and sixth centuries AD, seen as the period when Hinduism was firmly established) (6). Importance was also given to

(6) What is invariably overlooked, however, is the fact that the category 'Hinduism' serves little purpose in a Gupta 
locating on terra firma, events and places mentioned in shifting and polyvalent ancient 'Hindu' texts. Thus, projects such as the 'archaeology of the Ramayan sites' among others. gained predominance. In the mid-1970s, the areas around the Babri Masjid were excavated in order to identify their relation with the Ramayana. The reports of the findings (Lal, 1976-77) reveal no evidence of either a temple commemorating Rama's birth (Ramjanmabhoomi) or a Rama cult centre.

Evidently, unambiguous Islam with its focal point defined at Mecca required an 'answer' from ambiguous, multi-vocal, Hinduism and in the post-colonial era, Ayodhya began to be identified in the Hindu mind with the absolute position that Mecca appeared to have in the Muslim. The focus of this identification soon became the Babri Masjid. Although archaeological excavations in the area reveal no evidence of a (Ramjanmabhoomi) temple or Rama cult, the Hindus found in it, their answer to Mecca. Prior to the destruction of the mosque, the call to 'liberate' Rama from the 'prison' of the mosque, served to unify opposed, even warring Hindu factions, albeit superficially.

As the country experienced a Hindu resurgence, the archaeologist who had excavated the areas around the mosque and had reported (Lal, 1976-77) nothing of importance, stated in 1990,14 years after the publication of his findings, that evidence of a temple had in fact, been found in below-mosque strata. Although this announcement has not been accepted entirely by the archaeological community, it provided the fundamentalists with one of the weapons they needed. Clashes between the communities mounted and finally, the mosque was demolished by the Hindu fundamentalists in 1992. Few archaeologists protested publicly either at the revoking of the earlier statement (ie, Lal, 1976-77) and thereby at the mani-

context. The period witnessed the recension of old texts, allowing for new gods and cults. The old Vedic Brahmanism yielded to a Pauranicism with elements drawn form Roman, Mahayan and Chthonic elements (cf. Zimmen, 1948; Campbell, 1962). There is a need to critically re-examine the received truth of Gupta Hinduism/Nationalism. As Kosambi (1956) stated "It is not the Guptas who revived nationalism ... nationalism which revived the Guptas". It must also be noted that there is a vast difference between Guptan and contemporay Hindu Right versions of Hinduism (I thank R. Hoskote for the discussion we had on this). pulation of data for political purposes or at the destruction of an ancient monument. Those who did protest were viewed as 'reducing' archaeology to the level of politics. Once more, as in 1986, mainstream Indian archaeologists equated the taking of a stand against a reprehensible act as being political. Further, they did not condemn the act of destruction itself in any way. The Indian Archaeological Society was one of the few social science bodies that did not pass a resolution condemning the destruction of the mosque. While condemning the destruction has been viewed as 'political', not doing so has been seen as keeping 'clean' and refraining from 'dirtying' the hands in the 'political mess'. Such a desire to keep from taking ('political') stands has charac-terised Indian archaeologists and archaeology, even members of the WAC. This is curious, since the WAC states that it "is based on the explicit recognition of the historical and social role and political context of archaeological enquiry" and has "defined its role beyond its essentially academic functions and appreciates that ar-chaeology has a social as well as an academic responsibility" (WAC Aims and Application for Membership). Members evidently do not see the contradiction in holding the views they do while simultaneously belonging to the WAC community.

\section{POLITICS AND WAC-3}

Hence when WAC-3 was to be held in India, most archaeologists here did not consider it of significance that some of the organisers had been known to have (ab)used archaeology in the Babri Masjid issue. These were people who were always at the helm -at conferences, seminars, national and international, and their being invited to take up key positions in the management of WAC-3 was not seen as unusual. In fact, to the organisers, having these persons on the committee must have seemed expedient. Several people who later protested against the inclusion of persons in the committee, known to have been involved in the partisan rewriting of the past, at first offered their help in organising WAC-3, since it was not unusual that the names usually associated with any event in Indian archaeology were also associated with the Congress. It was only on reflection that protests began to be registered. Of course, archaeologists 
whose jobs or grants could have been at stake were wary of taking a stand against the establishment (Ucko reports how several people in the U.S. who supported the ban against South African/Namibian participation at WAC-1 were warned that their grants would be cut or their jobs taken) and it was left to those outside the system to protest against the misuse of archaeology and against the inclusion of those who had misused it, in the active organisation of WAC-3. It is significant that the first people to protest were from a department of history -among them were only a couple of archaeologists. But the WAC would go on without them since they had decided to boycott the event. Later, some archaeologists protested and decided not to boycott the WAC.

The group circulated a letter (signed by one member) to some archaeologists around the world, suggesting that the situation called for a speeial session to reflect on the issue of the Babri Masjid in the context of WAC and on the WAC itself: on why it came into being and what it stands for. The session could also help reiterate some of the early concerns that had been identified by WAC, Such reflection, undertaken seriously is obviously a matter of concern as it could result in radical alterations of existing power relations and structures. While several people supported such a session there were others who felt that the protest had come too late and still others who continued to feel that the session would only push archaeology further into the quagmire of politics.

As it turned out, the organisers ensured that neither the special session to reflect on the WAC was held, nor was any discussion permitted on the Babri Masjid issue and the outgoing President of the WAC was compelled to compromise the principles of the Congress and declare that no discussion on Ayodhya would be permitted within the Con-gress. Left without an option, those protesting against the inaction of WAC against (and there by the condoning of) archaeologists clearly known to have misused archaeology, decided to use the Plenary Session as a forum in which to voice their protests. Resolutions condemning the destruction of ancient monuments, the involvement of persons with partisan interests in the WAC and decrying the prevention of free and 'ultrammeled' debate at the Congress were to be proposed, debated and voted on. Unfortunately, the Plenary
Session of WAC-3 was reduced to complete chaos. Those opposed to the resolutions prevented discussions and a vote. The Chairman decided to dissolve the Session and a meeting of the Council was called.

Interestingly, although the Indian members at the Congress were overwhelmingly against the resolutions put forward condemning the destruction of ancient monuments and reiterating WAC's commitment to recognising the sociopolitical context of archaeological practice, the Council meeting inmmediately after the dissolving of the Plenary, adopted and then easily passed these resolutions. The situation calls for some reflection. If indeed most Indians present were against the resolution and felt strongly that archaeology and politics have no truck with each other, ought they to have joined a Congress that explicitly acknowledges the socio-political context of academics and archaeology? Further, a Council that appears not to represent the views of a majority of the delegates to the third Congress seems rather at variance with the stated intentions of WAC.

There is another point that must be reckoned with. The quiet and disciplined council meeting after the chaos of the Plenary Session, a meeting at which resolutions were passed in a sensible, reasonable manner could easily be constructed to exemplify the split between 'good reason' and the disorder that is expected at non-Western gatherings. The Council meeting could be identified as just one more way of re-asserting 'Western rationality' and 'reason' amidst the 'chaos' / 'emotionalism' represented by the South.

The special session that had been suggested for members to reflect on the WAC would have been the ideal forum within which to deba-te the issues of rival claims to sacred places (7), the abuse of archaeology for political purposes and of whether in fact, WAC had succeeded in attaining its objectives (of breaking hegemonic

(7) In this context it is essential to critically examine the issue of 'returning' sacred places. The issue has been approached in a rather simplistic manner in the West and requires reflection as is evident from the fact that it is an extremely complex affair in India (unlike perhaps, in Australia and the Americas), since several communities have, over centuries claimed sites as being sacred to them. Further, throughout history, sacred places have been used by successive groups to inscribe their power over the preceeding ones. Over the Ayodhya issue, the Hindu Right was confident of WAC 
domination in archaeology, of providing a forum for traditionally oppressed groups and creating a space for regional and social expressions). It would also have provided the much-required forum to discuss the contemporary violent expressions that regionalism and ethnicity have taken and to analyse the fall-out of the recent rejection of Western rationality as the 'universal' one. It is critical to examine the current meteoric rise of violent extremist/nationalistic rationalities as these are evidently not at play in India alone, and to investigate the space between Western ('universal') rationality and regional/ ethnic chauvinism. If the WAC refuses to permit such deliberation, it will have failed to have moved from its 1986 position of critiquing/ contesting what existed at the time, to developing alternative archaeologies and to become the relevant archaeological organisation for the next century.

The WAC is beyond doubt a well-meaning organisation that was set up with idealism and the determination that members would work together to further ethical research practices. Members of WAC would "not wish to stand aside and condone by inaction" since they are "immersed in the evidence of man's inhumanity to man over many time periods and in countless areas of the world" (Ucko, 1987: xi). But these ideals appear to be contrary to the events played out at WAC-3. WAC is the poorer for not permitting a debate on itself, its genesis, development and the fact that it "condone[d] by inaction" the usurpation by chauvinistic elements of the third Congress held in India in December 1994.

\section{ACKNOWLEDGMENTS}

I would like to thank M. ${ }^{a}$. Martínez Navarrete for inviting me to contribute to Trabajos de Prehistoria, F. Criado, M. ${ }^{\mathrm{a} J}$. Tallón and A. Hernando for their comments. I thank Rhys

support to its claim since the demand was for the returning of a 'sacred place'. But Ayodhya has been sacred to many (see Rao, 1994) - the Jains, Buddhists, Shaivas and Vaishnavas (who had bloody battles to retain it and re-inscribe their power through control of it) and Muslims. Who will return it then? and to whom? Since to return something also means that the one 'returning' has the power to do so.
Jones, Colin Renfrew, Roland Fletcher and Robert Layton for the discussions we had. I also thank R. Hoskote, R. Thapar, D. Mandal, R.S. Sharma and K.M. Shrimali for the conversations held. R. Boast, R. Bewley, P. Lane, G. Abungu, B. Olsen and I. Hodder provided much needed support and Rammanohar Reddy commented on the first draft.

\section{BIBLIOGRAPHY}

CAMPBEll, J. (1962): The Masks of God. Penguin. London. Champion, T. and Shennan, S. (1986): "Why the Congress had to go on". Archaeological Review from Cambridge, 5. 1: 109-113.

Historians' Forum (n. d.): Ramajanma Bhumi: Ayodhya: New Archaeological Discoveries. New Delhi. Historians' Forum.

Kosambi, D.D. (1956): An Introduction to the Study of Indian History. Popular Book Depot. Bombay.

LAL, B.B. (1976-77): Indian Archaeology-A Review, Archaeological Survey of India. New Delhi: 52-3.

LANGFORD, R.F. (1986): "Our Heritage - Your Playground". Australian Archaeology, 16: 1-6.

MANDAL, D. (1993): Ayodhya: Archaeology After Demolition. Orient Longman. New Delhi.

Miller, D. (1980): "Archaeology and Development". Current Anthropology, 21 (6): 709-715.

PRATAP, A. AND RAO, N. (1986): Theme editorial for issue "Archaeology and Politics". Archaeological Review from Cambridge, 5. 1: 2-3.

RAO, N. (1994): "Interpreting Silences: Symbol and History in the Case of Ram Janmabhoomi/Babri Masjid". In G. C. Bond and A. Gilliam (eds.): Social Construction of the Past: Representation as Power. One World Archaeology Series. Routledge. London: 154-64.

- (1987): Aspects of the Ethnoarchaeology of Adilabad (India). Ph. D. dissertation, Cambridge University. U. $\mathrm{K}$.

SAID, E. (1985): Orientalism. Penguin Books. Harmondsworth.

Shaw, T. (1986): "Archaeology and the Politics of Academic Freedom". Archaeological Review from Cambridge, 5. 1: 5-24.

SRIVASTAV, S. (1991): The Disputed Mosque: A Historical. Enquiry. Vistaar Publications. New Delhi.

Uско, P. J. (1987): Academic Freedom and Apartheid: the Story of the World Archaeological Congress, Duckworth. London.

Zimmer, H. (1948): The Art of Indian Asia. Pantheon Books. New York.

T. P., 52, n. ${ }^{\circ} 1,1995$ 